The Open Mechanical Engineering
Journal
CrossMark
Content list available at: www.benthamopen.com/TOMEJ/
DOI: $10.2174 / 1874155 \mathrm{X} 0161001000 \mathrm{c}$

\title{
Retraction Notice: An Analysis of the Vibration Characteristics of Automotive Exhaust Systems and Optimization of Suspension Points
}

\author{
Jian Min $\mathrm{Xu}^{*}$, Shuiting Zhou and Shui xuan Chen \\ School of Mechanical and Automotive Engineering, Xiamen University of Technology, Xiamen, 361024, P.R. China
}

\section{RETRACTION}

The Publisher and Editor have retracted this article [1] in accordance with good ethical practices. After thorough investigations we believe that the peer review process was compromised. The article was published online on $31-12-2014$.

\section{REFERENCE}

[1] J.M. Xu, S. Zhou, and S.X. Chen, "An Analysis of the Vibration Characteristics of Automotive Exhaust Systems and Optimization of Suspension Points", Open Mech. Eng. J., vol. 8, pp. 574-580, 2014.

(C) Xu et al.; Licensee Bentham Open.

This is an open access article licensed under the terms of the Creative Commons Attribution-Non-Commercial 4.0 International Public License (CC BY-NC 4.0) (https://creativecommons.org/licenses/by-nc/4.0/legalcode), which permits unrestricted, non-commercial use, distribution and reproduction in any medium, provided the work is properly cited.

* Address correspondence to this author at the School of Mechanical and automotive Engineering, Xiamen University of Technology, Xiamen, 361024, P.R. China; Tel: 13459263068; E-mail: xujianmin1020@163.com 